\title{
OTONOMI PENGELOLAAN ANGGARAN PEMERINTAH DAERAH: BAGAIMANAKAH DAMPAK TERHADAP KETIMPANGAN ANTAR WILAYAH DI JAWA TENGAH?
}

\author{
Herman Sambodo, Hary Pudjianto, Kikin Windhani dan Fajar Hardoyono \\ Universitas Jenderal Soedirman Purwokerto dan Institut Agama Islam Negeri Purwokerto \\ Email:sambodo.herman@gmail.com,hary.pudjianto@unsoed.ac.id, \\ kikin.windhani@unsoed.ac.id,dan hardoyono@iainpurwokerto.ac.id
}

\begin{abstract}
This study aims to analyze the influence of regional government financial management autonomy on the inequality between districts and cities in Central Java and to analyze the mapping of areas that have development priorities on social and economic indicators using Principal Component Analysis (PCA). This study uses economic growth variables, human development index, gross enrollment rate for senior high school (SMA) education, Williamson Index, and government spending in education. The analysis used was Panel Data Regression Analysis with the research object of 35 districts and cities in Central Java in the 2015-2019 period. The results show that there is a significant influence of local government spending on inequality between regions in Indonesia. Based on mapping using PCA, it can be seen that districts / cities in Central Java are divided into 3 clusters of regional grouping based on social and economic indicators.
\end{abstract}

Keywords: Autonomy of Budget Allocation, Inequality Between Regions, Principal Component Analysis (PCA).

\begin{abstract}
Abstrak
Penelitian ini bertujuan hendak menganalisis pengaruh otonomi pengelolaan keuangan pemerintah daerah terhadap ketimpangan antar wilayah kabupaten dan kota di Jawa Tengah serta menganalisis pemetaan wilayah yang memiliki prioritas pembangunan pada indikator sosial dan ekonomi dengan menggunakan Principal Component Analysis (PCA). Penelitian ini menggunakan variabel pertumbuhan ekonomi, indeks pembangunan manusia, angka partisipasi kasar pendidikan sekolah menengah atas (SMA), Indeks Williamson, Belanja pemerintah pada bidang pendidikan. Analisis yang digunakan adalah Analisis Regresi Data Panel dengan obyek penelitian 35 kabupaten dan kota di Jawa Tengah pada periode tahun 2015-2019. Hasil penelitian menunjukkan bahwa terdapat pengaruh yang signifikan variabel belanja pemerintah daerah terhadap ketimpangan antar wilayah di Indonesia. Berdasarkan mapping dengan menggunakan PCA dapat diketahui bahwa kabupaten/kota di Jawa Tengah terbagi menjadi 3 klaster pengelompokan wilayah berdasarkan indikator sosial dan ekonomi.
\end{abstract}

Kata kunci: Otonomi Alokasi Anggaran, Ketimpangan Antar Wilayah, Principal Component Analysis (PCA). 


\section{PENDAHULUAN}

Pelaksanaan otonomi daerah di Indonesia merupakan salah satu cara yang digunakan oleh pemerintah pusat untuk mendistribusikan sebagaian wewenangnya kepada pemerintah daerah. Salah satu bentuk kebijakan dalam implementasi otonomi daerah adalah pelaksanaan desentralisasi pusat ke daerah. Salah satu jenis desentralisasi adalah desentralisasi fiskal yang mengandung pengertian adanya pengalihan wewenang kepada pemerintah daerah dalam perencanaan, pengimplementasiaan dan pengawasaan pengelolaan fiskal secara efektif, efisien, akuntabel, dan transparan.

Hak pengelolaan fiskal kepada daerah otonom memungkinkan pemerintah daerah untuk merencanakan anggaran pendapatan dan pengeluaran secara lebih fleksibel untuk mendukung pelayanan masyarakat dan peningkatan kesejahteraan sosial berdasarkan skala prioritas. Dalam hal ini, pemerintah daerah dapat menyusun alokasi pendapatan dan belanja untuk semua sektor pelayanan publik yang berbeda dengan daerah lain. Secara umum, kebijakan alokasi anggaran disusun sedemikian rupa berdasarkan skala prioritas yang bertujuan untuk mewujudkan kesejahteraan dan keadilan sosial masyarakat.

Dua puluh tahun paska implementasi Undang-undang otonomi daerah dan desentralisasi fiskal memberikan hasil yang cukup positif terhadap proses pembangunan daerah. Indikator pembangunan ekonomi, sosial, dan infrastruktur paska otonomi daerah senantiasa menunjukkan tren ke arah positif. Namun di sisi lain, upaya desentralisasi fiskal belum mampu untuk menurunkan angka kemiskinan, menaikkan jumlah lapangan kerja di daerah serta menambah investasi di daerah. Fakta yang muncul justru ketimpangan anggaran pendapatan dan belanja daerah (APBD) yang signifikan antara daerah-daerah yang memiliki pendapatan asli daerah yang tinggi karena kaya akan sumber daya alam dengan daerah-daerah dengan daerah-daerah yang memiliki pendapatan asli daerah yang rendah karena miskin dengan sumber daya alam.

Ketimpangan ekonomi dan sosial juga terjadi yang dapat dilihat dari perbedaan pembangunan ekonomi dan sosial antar kabupaten/kota di wilayah Indonesia secara vertikal dan horizontal yang menyebabkan disparitas/kesenjangan indikator-indikator pembangunan ekonomi dan sosial. Faktafakta yang nampak sebagai wujud adanya ketimpangan ekonomi dan sosial diantaranya adalah disparitas yang tinggi dalam hal capaian produk dosmetik regional bruto, jumlah pengangguran, angka kemiskinan, indeks pembangunan manusia, angka partisipasi kasar pendidikan, dan indeks kesehatan masyarakat (Badan Pusat Statistik, 2019).

Jawa Tengah merupakan salah satu provinsi yang berada di pulau Jawa, merupakan salah satu provinsi yang memiliki jumlah penduduk terbesar di Jawa. Selain itu provinsi Jawa Tengah merupakan salah satu provinsi yang menopang kebutuhan pangan agraris dan usaha mikro kecil menengah untuk tingkat nasional serta merupakan salah satu pusat pertumbuhan ekonomi di Indonesia. Pada sisi yang lain ternyata Provinsi Jawa Tengah masih memiliki ratarata tingkat kemiskinan yg masih tinggi yaitu masih pada angka 11,2 \%, masih berada di atas angka nasional. Kemudian tingkat HDI masih berada pada rangking ke 14 nasional, angka partisipasi sekolah juga masih berada di bawah nasional dengan angka 84,35\% dan di bidang kesehatan masih sekitar 32,72 $\%$ penduduk Jawa Tengah mengalami masalaha kesehatan (Badan Pusat Statistik, 2019).

Hasil-hasil penelitian terdahulu banyak melaporkan penggunaan APBD kabupaten/kota banyak lebih banyak dialokasikan untuk program-program yang tidak berkaitan langsung dengan kesejahteraan masyarakat seperti belanja pegawai, biaya perjalanan dinas, rehabilitasi kantor/gedung pemerintah, dan tunjangan jabatan kepala daerah, anggota DPRD, dan pegawai pemerintah daerah. Penelitian 
(Waluyo, 2010) melaporkan tentang banyaknya pemerintah kabupaten/kota yang mengalokasikan APBD untuk belanja pegawai melebihi angka $70 \%$ dari total APBD. Fakta ini diperkuat dengan pemberitaan dari detikfinance yang memberitakan bahwa masih terdapat 131 pemerintah kabupaten/kota di Indonesia yang mengalokasikan belanja pegawai di atas 50\% dari total APBD pada tahun 2017 (Rachman, 2017).

Bedasarkan latar belakang di atas, maka penulis merasa perlu menganalisis pengaruh otonomi pengelolaan keuangan pemerintah daerah terhadap ketimpangan antar wilayah kabupaten dan kota di Jawa Tengah serta menganalisis pemetaan wilayah yang memiliki prioritas pembangunan pada indikator sosial dan ekonomi dengan menggunakan Principal Component Analysis (PCA).

\section{LITERATURE REVIEW}

Waluyo (2010) melakukan penelitian tentang masih banyaknya pemerintah kabupaten/kota di Indonesia yang melalokasikan anggaran untuk belanja pegawai. Masih terdapat 10 pemerintah kabupaten/kota di Indonesia yang mengalokasikan APBD untuk belanja pegawai hingga melebihi angka $70 \%$ dari total APBD.

Penelitian (Wandira, 2013) meneliti pengaruh Pendapatan Asli Daerah (PAD), Dana Alokasi Umum (DAU), Dana Alokasi Khusus (DAK) dan Dana Bagi Hasil (DBH) terhadap alokasi belanja modal pemerintah daerah provinsi se-Indonesia pada tahun 2012. Hasil penelitian melaporkan bahwa DAU dengan arah negatif, DAK dan DBH berpengaruh signifikan terhadap belanja modal. Sedangkan PAD tidak berpengaruh signifikan terhadap belanja modal.

Penelitian (Xiajing \& Junjie, 2011) meneliti tentang kesenjangan pembangunan ekonomi yang terjadi di 11 kota Cina. Indikator makroekonomi yang digunakan untuk mengukur terjadinya kesenjangan ekonomi meliputi pendapatan perkapita, GDP, total penjualan barang retail, komposisi GDP, total investasi, total laba perusahaan, pendapatan perkapita tahunan rumah tangga, jumlah tabungan yang dimiliki oleh rumah tangga, jumlah proyek investasi dan nilai ekspor dan impor. Analisis Technique for Order Preference by Similarity to Ideal Solution (TOPSIS) digunakan untuk melakukan pemetaan kesenjangan pembangunan ekonomi yang terjadi pada 11 kota yang diteliti. Analisis TOPSIS berhasil memetakan kota-kota yang mengalami ketertinggalan pembangunan ekonomi dibandingkan dengan kota lain berdasarkan 11 parameter makroekonomi.

Penelitian (Lee, 2011) mengkaji tentang pola pembangunan dan kesenjangan ekonomi yang terjadi pada 6 kota metropolitan di USA tahun 1970-2000. Pembangunan yang terjadi secara masif terhadap 6 kota metropolitan di Amerika Serikat sejak tahun 1970-2000 menyebankan terjadinya kesenjangan sosial ekonomi antara wilayah desa dan perkotaan.

Penelitian (Sharma, 2012) melakukan penelitian tentang kesenjangan pembangunan ekonomi yang terjadi antar wilyah di India utara. Kesenjangan pembangunan diukur dengan menggunakan 27 indikator makroekonomi diantaranya adalah jumlah penduduk, pendapatan perkapita, jumlah investasi, tabungan masyarakt, dan produk domestik regional bruto, dan pertumbuhan ekonomi. Metode composit index digunakan untuk menganalisis wilayah yang mengalami ketertinggalan ekonomi dibandingkan dengan daerah lain berdarkan 27 indikator makroekonomi.

Penelitian (Guo-yong, 2010) melakukan penelitian tentang pemetaan jejaring inovasi antar daerah dalam pola pembangunan di Cina dengan menggunakan Principal Component Analysis (PCA). Indikator yang digunakan untuk mengukur inovasi daerah dalam meningkatkan pembangunan ekonomi wilayah meliputi jumlah perguruan tinggi yang ada di daerah, pendapatan perkapita wilayah, jumlah lowongan kerja yang ditawarkan, volume perdagangan, ketergantungan daerah 
terhadap barang impor, jumlah uang beredar, nilai kontrak perdagangan produk terknologi. Analisis dengan menggunakan PCA berhasil memetakan wilayah-wilayah yang kurang inovatif dalam upaya menggerakkan ekonomi.

Penelitian (Qin-dong \& Jing, 2010) melakukan penelitian tentang evaluasi kemampuan inovasi daerah dalam proses pembangunan di Cina. Indiktor yang digunakan untuk mengukur inovasi daerah dalam percepatan pembangunan adalah pengetahuan masyarakat, kemajuan sains dan teknologi di wilayah setempat, kekuatan ekonomi dan kinerja institusi pemerintah daerah. Dari aspek kekuatan ekonomi, varaiabel yang digunakan untuk mengukur kemampauan inovasi daerah dalam menggerakkan pembangunan meliputi pendaptan perkapita, jumlah industri berat, sedang, dan kecil, volume penjualan produk teknologi, dan pendapatan rumah tangga masyarakat. Analisis PCA berhasil mengelompokkan daerah yang kurang inovatif dan lambat dalam proses pembangunan.

Penelitian (Clausen, 2010) melakukan penelitian tentang globalisasi ekonomi dan kesenjangan antar wilayah yang terjadi di Filipina. Globalisasi ekonomi memberikan dampak terjadinya kesenjangan pembangunan ekonomi antar wilayah di Filipina. Pertumbuhan ekonomi hanya berpusat di kota-kota besar di Filipina. Terjadi ketimpangan yang signifikan antara pusat- pusat pertumbuhan di kota-kota besar dengan wilayah-wilayah pedaman di Filipina. Indikator yang digunakan untuk mengukur terjadinya ketimpangan pembangunan ekonomi antar wilayah adalah pendapatan perkapita, Produk Domestik Regional Bruto (PDRB), jumlah penduduk, volume hasil produk pertanian, pendapatan rumah tangga masyarakat, volume perdagangan barang, dan jasa.

\section{KONSEP DASAR}

\section{Pembangunan Nasional}

Menurut GBHN 1999, pembangunan nasional merupakan rangkaian upaya pembangunan yang berkesinambungan, yang meliputi seluruh kehidupan masyarakat, bangsa dan negara untuk mewujudkan tujuan nasional yang termaktub dalam Undangundang Dasar 1945 yaitu melindungi segenap bangsa Indonesia dan seluruh tumpah darah Indonesia, memajukan kesejahteraan umum, mencerdaskan kehidupan bangsa, dan ikut mewujudkan ketertiban dunia berdasarkan kemerdekaan, perdamaian abadi dan keadilan sosial. Salah satu prinsip pembangunan nasional yang disebutkan dalam UU No. 25 tahun 2000 tentang sistem perencanaan pembangunan nasional adalah menyelenggarakan pembangunan nasional berdasarkan demokrasi dengan prinsip kebersamaan, berkeadilan, berkelanjutan, berwawasan lingkungan, serta kemandirian dengan menjaga keseimbangan kemajuan dan kesatuan Nasional. Prinsip kebersamaan dan keadilan sosial merupakan prinsip utama pembangunan.

Arah pembangunan nasional di Indonesia diarahkan pada pembangunan fisik dan non fisik. Selain pembangunan sarana infrastruktur seperti jalan dan jembatan, pembangunan non fisik seperti pengurangan tingkat kemiskinan, penanggulangan ketimpangan pendapatan, dan penyediaan lapangan kerja dalam konteks perekonomian yang terus berkembang (Todaro \& Smith, 2006). Sesuai dengan tujuan pembangunan tersebut pembangunan suatu negara boleh dikatakan tidak berhasil apabila tidak dapat mengurangi kemiskinan, memperkecil ketimpangan pendapatan serta menyediakan lapangan kerja yang cukup bagi penduduknya.

Untuk mengukur keberhasilan pembangunan tidak cukup hanya menggunakan tolok ukur ekonomi saja melainkan juga harus didukung oleh indikator-indikator sosial (non ekonomi), antara lain seperti tingkat melek huruf, tingkat pendidikan, kondisi-kondisi dan kualitas 
pelayanan kesehatan, kecukupan akan kebutuhan perumahan (Todaro \& Smith, 2006). Selain itu, ukuran keberhasilan pembangunan nasional dengan pemenuhan dasar kebutuhan material individu termasuk makanan, pakaian, dan tempat tinggal, dan secara bertahap mencapai tingkat tertinggi pemenuhan diri. Bentuk yang paling penting dari pemenuhan diri termasuk kehidupan yang panjang sehat, terdidik, dan menikmati standar hidup layak. Ukuran keberhasilan pembangunan nasional menggabungkan dimensi ekonomi, sosial-psikologi dan politik. Kesejahteraan sosial dapat diukur juga dengan menggunakan parameter kemajuan sosial dan ekonomi (Noll, 2002). Parameter kemajuan sosial itu meliputi rasio pekerja dengan pengangguran, rasio masyarakat berpendidikan dengan tidak berpendidikan, standar hidup, kualitas kesehatan, perlindungan sosial, keamanan sosial, tingkat kriminalitas, kualitas transportasi, dan kondisi lingkungan.

\section{Pembangunan}

\section{Kesejahteraan Masyarakat}

Kesejahteraan masyarakat menjadi tolak ukur utama dalam mengukur keberhasilan pembangunan di suatu wilayah. Berkurangnya angka kemiskinan merupakan juga merupakan salah satu indikator keberhasilan pembangunan di suatu wilayah. Definisi dan indikator tentang kemiskinan sangat banyak. Menurut Mubyarto sebagaimana dikutip oleh (Amalia, 2012) kemiskinan digambarkan sebagai kurangnya pendapatan untuk memenuhi kebutuhan hidup minimum yaitu sandang, pangan dan papan. Indikator yang digunakan untuk mengukur angka kemisikinan diantaranya adalah tingkat konsumsi beras perkapita per tahun, tingkat pendapatan dan indikator kesejahteraan masyarakat (Arsyad, 2010). Sementara itu, Bank dunia mendefinisikan seseorang dianggap miskin apabila memiliki pendapatan rata-rata kurang dari US \$ 2 dalam sehari di negara berkembang seperti di Indonesia (Fahmi \& Hendrawan, 2007).

Selain indikator peningkatan pertumbuhan ekonomi dan penurunan angka kemiskinan, keberhasilan pembangunan juga diukur dari peningkatan kualitas kesehatan dan pendidikan. Penggunaan ukuran PDRB hanya sekedar mengukur pertumbuhan ekonomi, sementara perbaikan dan peningkatan kualitas kesehatan dan pendidikan mencerminkan keberhasilan pembangunan sosial masyarakat.

\section{Pokok-pokok Pengelolaan Keuangan Daerah}

Pokok-pokok pengelolaan keuangan daerah secara eksplisit diatur melalui Undangundang No. 17 tahun 2003 tentang keuangan negara serta Peraturan Pemerintah No. 58 tahun 2005 tentang pengelolaan keuangan daerah dan Peraturan Menteri dalam Negeri No. 33 tahun 2017 tentang pedoman penysunan APBD tahun anggaran 2018. Peraturan Pemerintah ini mengatur tentang definisi, sumber, pengalokasian, serta pengelolaan keuangan daerah. Keuangan daerah dikelola oleh pejabat pemerintah daerah melalui instrumen Anggaran Pendapatan dan Belanja Daerah (APBD) yang disusun oleh pemerintah daerah dan disetujui oleh Dewan Perwakilan Rakyat Daerah (DPRD). APBD bersumber dari Pendapatan Asli Daerah (PAD), Dana Alokasi Umum (DAU), Dana Alokasi Khusus (DAK), Dana Bagi Hasil (DBH), Pendapatan Hibah Pemerintah Daerah (DH) dan sumber pendapatan daerah yang lain. APBD yang telah disusun oleh pemerintah daerah dan disetujui oleh DPRD selanjutnya dialokasikan untuk program-program pembangunan di daerah. APBD umumnya alokasi untuk belanja pegawai, belanja barang dan jasa, belanja pemeliharaan, belanja perjalanan dinas, serta subsidi/bantuan.

\section{Disparitas Ekonomi dan Sosial}

Pembangunan ekonomi sebagai suatu proses yang mencakup perubahan struktur, sikap hidup, kelembagaan, selain mencakup peningkatan pertumbuhan ekonomi, pengurangan ketidakmerataan distribusi pendapatan dan pemberantasan kemiskinan. 
Akibat adanya perbedaan dan keragaman potensi sumber daya alam, letak geografis, dan kualitas sumber daya manusia di berbagai wilayah Indonesia yang diikuti dengan perbedaan kinerja setiap daerah telah menyebabkan terjadinya ketimpangan pembangunan antar wilayah (Todaro \& Smith, 2006). Ketimpangan pembangunan antar wilayah selanjutnya dapat dibedakan menjadi ketimpangan ekonomi, ketimpangan sosial, dan ketimpangan infrastruktur.

Untuk mengetahui ketimpangan pendapatan yang terjadi di Jawa Tengah digunakan perhitungan Indeks Williamson (Arsyad, 2010). Dalam perhitungannya, Indeks Williamson menggunakan Produk Domestik Regional Bruto (PDRB) perkapita dan jumlah penduduk sebagai data dasar. Adapun Indeks Williamson secara statistik dapat diformulasikan sebagai berikut :

$$
V w=\frac{\sum\left(Y_{i}-Y\right)^{2}}{Y} \cdot \frac{f_{i}}{n}
$$

Dimana $V_{w}$ adalah nilai indeks Williamson, $\mathrm{Y}_{\mathrm{i}}$ adalah PDRB per kapita di wilayah ke i, Y adalah PDRB per kapita seluruh wilayah, $\mathrm{f}_{\mathrm{i}}$ adalah jumlah penduduk di wilayah ke i, dan $\mathrm{n}$ adalah jumlah penduduk seluruh wilayah. Nilai indeks berada pada angka 0 sampai dengan 1 , mendekati 1 maka ketimpangan semakin besar dan mendekati 0 maka ketimpangan semakin kecil atau semakin merata.

\section{METODE PENELITIAN}

Jenis penelitian yang dilakukan adalah penelitian survey dengan pendekatan kuantitatif. Peneliti hendak melakukan survai data tentang kapasitas fiskal daerah kabupaten/kota di Jawa Tengah, peta disparitas wilayah berdasarkan indikator ekonomi dan sosial, serta pengaruh desentralisasi fiskal terhadap disparitas wilyah untuk periode lima tahunan sejak 2015-2019. Variabel yang hendak diukur dari penelitian ini adalah:

1. Peta pembangunan pemerintah
daerah kabupaten/kota di Jawa
Tengah periode 2015-2019 berdasarkan indikator ekonomi dan sosial

2. Disparitas sosial yang diukur dari angka kemiskinan, rasio pengangguran dibandingkan jumlah penduduk, usia harapan hidup, indeks pembangunan manusia, dan angka partisipasi pendidikan periode 20152019.

Pengumpulan data dilakukan dengan dengan cara penelusuran internet. Beberapa laman yang digunakan untuk memperoleh data adalah sebagai berikut:

1. Laman Kementerian Keuangan RI untuk memperoleh data tentang indeks kapasitas fiskal seluruh pemerintah kabupaten/kota di Indonesia.

2. Laman Badan Pusat Statistik untuk memperoleh data makroekonomi di seluruh pemerintah kabupaten/kota di Indonesia yang meliputi jumlah penduduk, PDRB, pendapatan perkapita, angka kemiskinan, jumlah pengangguran, indeks pembangunan manusia dan angka partisipasi pendidikan.

Analisis data dilakukan menggunakan teknik:

1. Pengaruh desentraliasi fiskal terhadap disparitas ekonomi dan sosial dianalisis menggunakan analisis regresi berganda. Persamaan regresi berganda yang hendak dihitung adalah $\mathrm{Y}=\mathrm{a}+\mathrm{bX} \mathrm{X}_{\mathrm{it}}$; dengan $Y$ adalah variabel ketimpangan pendapatan, $x_{1}$ adalah variabel indikator ekonomi/sosial dan $b$ adalah tetapan. Besar pengaruh desentralisasi anggaran terhadap indikator ekonomi dan sosial dihitung dari nilai koefisien determinasi (adjusted $\mathrm{R}^{2}$ )

2. Pemetaan disparitas ekonomi dan sosial pada wilayah kabupaten/kota di Indonesia menggunakan principal component analysis (PCA), serta analisis klaster sebagaimana pernah dilakukan oleh (Qin-dong \& Jing, 2010). Simulasi hasil interpolasi data 
ditampilkan pada Gambar 1.

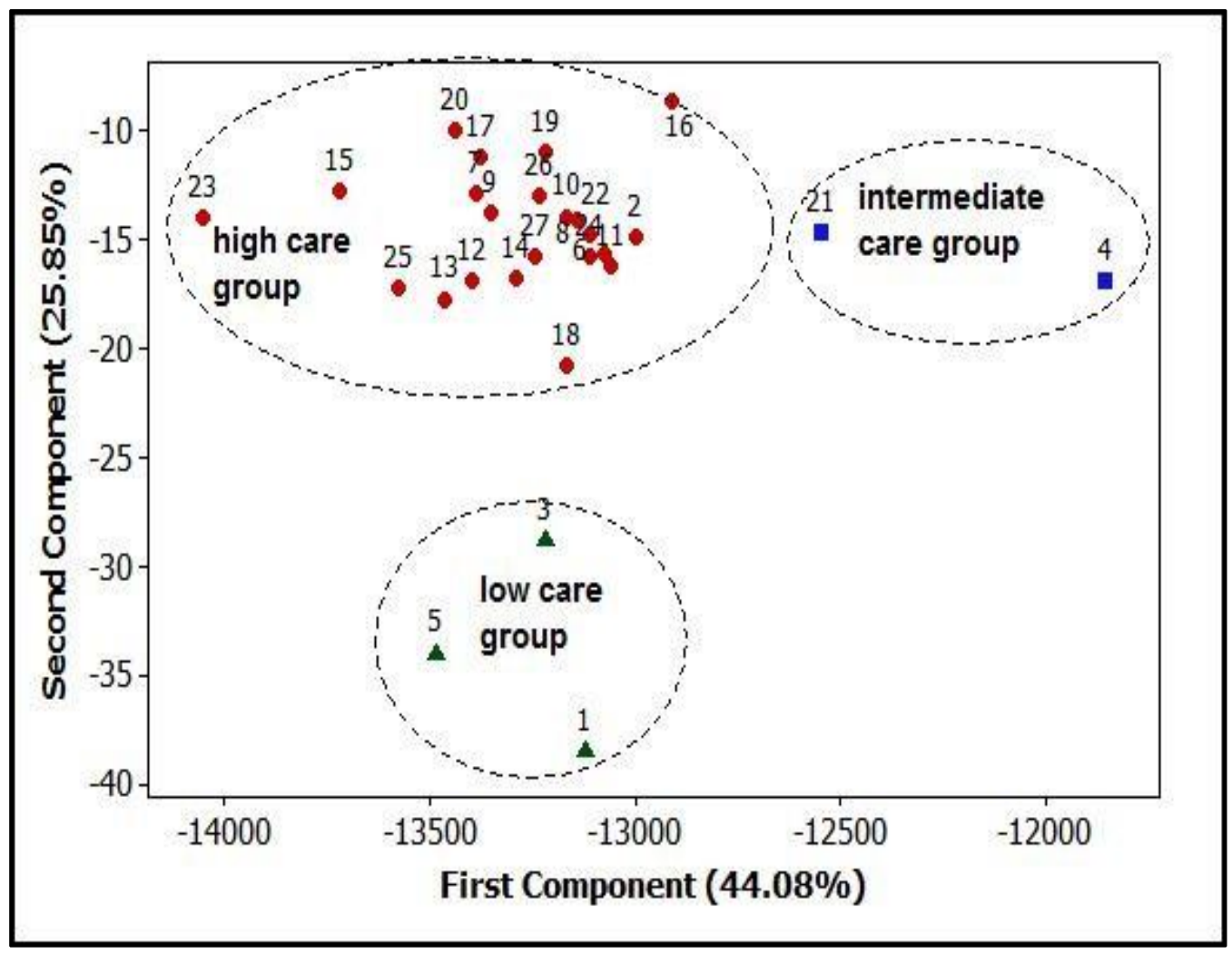

Gambar 1. Simulasi hasil interpolasi variabel principal component pertama $\left(\mathrm{PC}_{1}\right)$ dan principal component kedua $\left(\mathrm{PC}_{2}\right)$ untuk pemetaan disparitas ekonomi dan sosial

PEMBAHASAN DAN DISKUSI

Principal Component Analysis (PCA)

Berdasarkan analisis principal component analysis (PCA) dapat diketahui bahwa wilayah kabupaten/kota di Jawa Tengah terbagi menjadi tiga wilayah klaster utama yaitu klaster wilayah dengan profil indikator ekonomi dan sosial yang sangat tinggi. Klaster wilayah dengan profil indikator ekonomi dan sosial yang tinggi serta klaster wilayah dengan profil indikator ekonomi dan sosial yang sedang. Hasil analisis dengan PCA dapat dilihat pada Tabel 1 berikut:

Tabel 1. Hasil Klasterisasi dengan PCA Kabupaten/Kota di Jawa Tengah berdasarkan Indikator Ekonomi dan Sosial

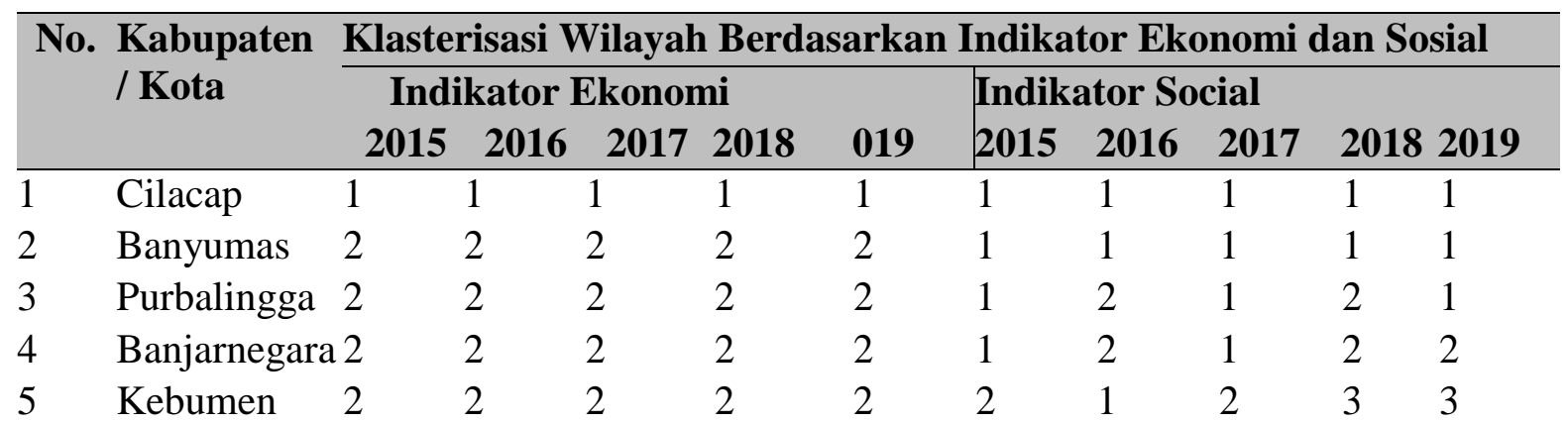




\begin{tabular}{|c|c|c|c|c|c|c|c|c|c|c|c|}
\hline \multirow{3}{*}{\multicolumn{2}{|c|}{$\begin{array}{l}\text { No. Kabupaten } \\
\text { / Kota }\end{array}$}} & \multicolumn{10}{|c|}{ Klasterisasi Wilayah Berdasarkan Indikator Ekonomi dan Sosial } \\
\hline & & \multicolumn{4}{|c|}{ Indikator Ekonomi } & \multirow[b]{2}{*}{019} & \multicolumn{4}{|c|}{ Indikator Social } & \multirow[b]{2}{*}{2019} \\
\hline & & 2015 & 2016 & 2017 & 2018 & & 2015 & 2016 & 2017 & 2018 & \\
\hline 6 & Purworejo & 2 & 2 & 2 & 2 & 2 & 2 & 1 & 2 & 3 & 3 \\
\hline 7 & Wonosobo & 2 & 2 & 2 & 2 & 2 & 3 & 2 & 1 & 2 & 2 \\
\hline 8 & Magelang & 2 & 2 & 2 & 2 & 2 & 3 & 1 & 1 & 2 & 1 \\
\hline 9 & Boyolali & 2 & 2 & 2 & 2 & 2 & 2 & 1 & 1 & 1 & 1 \\
\hline 10 & Klaten & 2 & 2 & 2 & 2 & 2 & 2 & 1 & 2 & 3 & 3 \\
\hline 11 & Sukoharjo & 2 & 2 & 2 & 2 & 2 & 2 & 3 & 3 & 1 & 3 \\
\hline 12 & Wonogiri & 2 & 2 & 2 & 2 & 2 & 2 & 1 & 2 & 3 & 3 \\
\hline 13 & Karanganyar & 2 & 2 & 2 & 2 & 2 & 2 & 3 & 3 & 1 & 3 \\
\hline 14 & Sragen & 2 & 2 & 2 & 2 & 2 & 2 & 1 & 2 & 3 & 3 \\
\hline 15 & Grobogan & 2 & 2 & 2 & 2 & 2 & 1 & 1 & 1 & 2 & 2 \\
\hline 16 & Blora & 2 & 2 & 2 & 2 & 2 & 1 & 1 & 1 & 2 & 1 \\
\hline 17 & Rembang & 2 & 2 & 2 & 2 & 2 & 1 & 2 & 1 & 2 & 1 \\
\hline 18 & Pati & 2 & 2 & 2 & 2 & 2 & 1 & 1 & 1 & 1 & 1 \\
\hline 19 & Kudus & 1 & 1 & 3 & 3 & 3 & 1 & 3 & 3 & 1 & 3 \\
\hline 20 & Jepara & 2 & 2 & 2 & 2 & 2 & 1 & 1 & 1 & 1 & 1 \\
\hline 21 & Demak & 2 & 2 & 2 & 2 & 2 & 1 & 1 & 1 & 1 & 1 \\
\hline 22 & Semarang & 2 & 2 & 2 & 2 & 2 & 1 & 1 & 1 & 1 & 1 \\
\hline 23 & Temanggung & 2 & 2 & 2 & 2 & 2 & 3 & 1 & 1 & 1 & 1 \\
\hline 24 & Kendal & 2 & 2 & 2 & 2 & 2 & 1 & 1 & 1 & 1 & 1 \\
\hline 25 & Batang & 2 & 2 & 2 & 2 & 2 & 1 & 1 & 1 & 2 & 1 \\
\hline 26 & Pekalongan & 2 & 2 & 2 & 2 & 2 & 3 & 2 & 1 & 2 & 2 \\
\hline 27 & Pemalang & 2 & 2 & 2 & 2 & 2 & 3 & 2 & 1 & 2 & 2 \\
\hline 28 & Tegal & 2 & 2 & 2 & 2 & 2 & 1 & 1 & 1 & 2 & 1 \\
\hline 29 & Brebes & 2 & 2 & 2 & 2 & 2 & 3 & 2 & 1 & 2 & 2 \\
\hline 30 & Magelang* & 3 & 3 & 1 & 1 & 1 & 2 & 3 & 3 & 1 & 3 \\
\hline 31 & Surakarta* & 1 & 1 & 1 & 1 & 1 & 2 & 3 & 3 & 1 & 3 \\
\hline 32 & Salatiga* & 3 & 3 & 1 & 1 & 1 & 1 & 3 & 3 & 1 & 3 \\
\hline 33 & Semarang* & 1 & 1 & 3 & 3 & 3 & 2 & 3 & 3 & 1 & 3 \\
\hline 34 & Pekalongan* & 2 & 2 & 2 & 2 & 2 & 1 & 1 & 1 & 1 & 1 \\
\hline 35 & Tegal* & 3 & 3 & 1 & 1 & 1 & 2 & 1 & 1 & 1 & 1 \\
\hline
\end{tabular}

Sumber: Data sekunder, 2020 (diolah)

Keterangan:

1: wilayah dengan profil sangat tinggi dalam indikator makroekonomi dan sosial

2: wilayah dengan profil tinggi dalam indikator makroekonomi dan sosial

3: daerah dengan profil sedang dalam indikator makroekonomi dan sosial

Berdasarkan Tabel 1 dapat dilihat bahwa sebagian besar wilayah di Provinsi Jawa Tengah memiliki kinerja indikator makroekonomi yang tinggi dan tergolong dalam klaster 2. Hanya 2 wilayah yaitu Kabupaten Cilacap dan Kota Surakarta yang memiliki indikator perekonomian yang stabil dan sangat tinggi sejak tahun 2015-2019. Kabupaten Kudus dan Kota Semarang menurunkan level indikator makroekonomi klaster 1 (profil sangat tinggi) ke klaster 3 (profil sedang). Sedangkan Kota Magelang, Kota Salatiga, dan Kota Tegal mengalami peningkatan dari klaster 3 
menjadi kluster 1 dalam 5 tahun sejak tahun 2015. Loading plot PCA menunjukkan bahwa indikator kontribusi ekonomi dan belanja pemerintah menyumbang data varian tertinggi dari indikator makroekonomi sedangkan tingkat inflasi menyumbang varian terendah.

Data indikator sosial 35 daerah di Provinsi Jawa Tengah lebih dinamis dibandingkan data makroekonomi pada tahun yang sama. Data indikator sosial pada Tabel 3 menunjukkan bahwa 7 wilayah yaitu Kabupaten Cilacap, Kabupaten Banyumas, Kabupaten Pati, Kabupaten Jepara, Kabupaten Demak Kabupaten Semarang dan Kabupaten Kendal memiliki kinerja yang sangat tinggi dalam indikator sosial. Tiga daerah yaitu Kabupaten Boyolali, Kabupaten Temanggung, dan Kabupaten Tegal mengalami peningkatan kinerja indikator sosial dan perubahan posisi klaster dari klaster 2 menjadi klaster 1. Sedangkan Kabupaten Grobogan merupakan satu-satunya daerah yang mengalami downgrade dari klaster 1 ke klaster 2 sejak tahun 2015 hingga 2019. Lainnya 24 wilayah melakukan posisi swing cluster dari tahun 2015 hingga 2019. Loading plot PCA menggunakan 5 indikator sosial menunjukkan bahwa indikator angka partisipasi pendidikan menyumbang varian data terendah pada indikator sosial. Sedangkan indikator angka harapan hidup, IPM, angka kemiskinan, dan angka pengangguran memiliki kontribusi yang sama terhadap varians data indikator sosial.

\section{Pengaruh otonomi pengelolaan keuangan pemerintah daerah terhadap ketimpangan antar wilayah kabupaten dan kota di Jawa Tengah}

Berdasarkan hasil uji regresi data panel antara tahun 2015-2019 dapat diketahui bahwa model sudah merepresentasikan model yang baik dengan nilai adjusted R2 0,946, artinya bahwa 94,6 persen variabel bebas menjelaskan variabel terikatnya, sedangkan sisanya sebesar 5,4 persen dijelaskan variabel lain yang tidak berada dalam model. Variabel bebas yang digunakan adalah Angka Partisipasi Kasar (APK), proporsi anggaran pemerintah untuk pendidikan (Pendidikan), pertumbuhan ekonomi (PE), jumlah penduduk dan kemiskinan. Sedangkan variabel terikatnya adalah Indeks Wiliamson sebagai ukuran ketimpangan antar wilayah.

Pengaruh distribusi sumber daya manusia dan anggaran pemerintah daerah pada bidang pendidikan terhadap ketimpanagan antar wilayah di Jawa Tengah dianalisis dengan menggunakan analisis regresi data panel dengan data kurun waktu 2015-2019, dapat dilihat pada Tabel 2 sebagai berikut:

Tabel 2. Hasil uji regresi data panel

\begin{tabular}{llc}
\hline \multicolumn{1}{c}{ Variabel } & Koefisien & Probabilitas \\
\hline C & 8.819422 & 0.1777 \\
APK & -0.000082 & 0.8050 \\
PENDIDIKAN & -0.0000926 & 0.0162 \\
PE & -0.007178 & 0.3185 \\
IPM & -0.038579 & 0.0000 \\
LN_PENDUDUK & -0.408530 & 0.4200 \\
KEMISKINAN & 0.009745 & 0.0418 \\
\hline
\end{tabular}

Adjusted R ${ }^{2} 0.946769$

Sumber: data sekunder, 2020 (diolah) 
Variabel yang signifikan adalah Pendidikan, IPM dan Kemiskinan dengan angka probabilitas dibawah $\alpha$ sebesar $5 \%$. Sedangkan variabel APK, PE dan Jumlah penduduk tidak signifikan berpengaruh terhadap ketimpangan antar wilayah.

Variabel proporsi anggaran pendidikan berpengaruh negatif dan signifikan terhadap ketimpangan antar wilayah yaitu jika variabel proporsi anggaran pendidikan naik sebesar Rp. 100.000 maka akan menurunkan ketimpangan antar wilayah sebesar 9,26 persen. Hal ini berarti bahwa kenaikan proporsi pengeluaran pemerintah dalam bidang pendidikan mampu mengurangi ketimpangan antar wilayah. Sehingga pemerintah daerah sebaiknya mengaloksikan penegeluaran untuk pendidikan lebih besar sehingga ketimpangan dapat menurun

Variabel IPM berpengaruh negatif dan signifikan terhadap ketimpangan antar wilayah yaitu jika IPM naik 1 prosen maka akan menurunkan tingkat ketimpangan antar wilayah sebesar 0,0385 persen. Hal ini berarti bahwa indikator modal manusia merupakan hal penting dalam rangka penurunan angka ketimpangan antar wilayah di Jawa Tengah. Sehingga pemerintah kabupaten/kota di Jawa Tengah dapat memprioritaskan pembangunan pada peningkatan sumber daya manusia.

Variabel yang terakhir yang signifikan berpengaruh adalah kemiskinan dengan arah pengaruh positif yaitu jika angka kemiskinan turun sebesar 1 persen maka akan menurunkan tingkat ketimpangan antar wilayah sebesar 0,0097 persen. Hal ini berarti bahwa tingkat kemiskinan antar kabupaten/kota di Jawa Tengah merupakan faktor penting penyumbang tingkat ketimpangan antar wilayah, maka kebijakan yang dilakukan oleh pemerintah adalah bagaimana memprioritaskan pembangunan pada prioritas mengurangi tingkat kemiskinan masyarakat. Hal yang dapat dilakukan adalah dengan melalui pemberdayaan masyarakat-masyarakat miskin dengan program produktif dari pemerintah untuk meningkatkan pendapatan masyarakat.

\section{KESIMPULAN}

Beberapa hal yang dapat disimpulkan dari penelitian ini adalah bahwa sebagian besar kabupaten/kota di Jawa Tengah berdasarkan analisis Principal Component Analysis masuk dalam kategori wilayah dengan profil tinggi dalam indikator ekonomi makro dan indikator sosial. Hanya beberapa wilayah saja yang berada pada wilayah profil sangat tinggi dan sedang. Variabel proporsi pengeluaran pemerintah untuk pendidikan (Pendidikan), IPM dan tingkat kemiskinan merupakan variabel yang berpengaruh signifikan terhadap ketimpangan antar wilayah kabupaten/kota di Jawa Tengah. Sedangkan variabel pertumbuhan ekonomi, angka partisipasi kasar pendidikan dan jumlah penduduk tidak berpengaruh signifikan terhadap ketimpangan antar wilayah.

\section{DAFTAR PUSTAKA}

Amalia, F. (2012). Pengaruh Pendidikan, Pengangguran dan Inflasi terhadap Tingkat Kemiskinan di Kawasan Timur Indonesia (KTI) Periode 20012010. EconoSains, 158-169.

Arsyad, L. (2010). Ekonomi Pembangunan. Yogyakarta: UPP STIM YKPN.

Badan Pusat Statistik. (2019). Jawa Tengah dalam Angka 2019. Semarang: Badan Pusat Statistik.

Badan Pusat Statistik. (2019). Statistik Kemiskinan dan Kesetaraan Indonesia. Jakarta: Badan Pusat Statistik.

Clausen, A. (2010). Economic globalization and regional disparities in the Philippines. Singapore Journal of Tropical Geography, 299-316.

Fahmi, I., \& Hendrawan, S. (2007). Kemiskinan versus Pertanian. Agrimedia, 1-6.

Guo-yong, M. A. (2010). Evaluation of regional innovation networks: based 
on principal component analysis. Canadian Social Science, 34 - 43.

Lee, S. (2011). Metropolitan Growth Patterns and Metropolitan Growth Patterns and Metropolitan Areas 1970-2000. International Journal of Urban and Regional Research, 988-1011.

Qin-dong, L. I., \& Jing, N. (2010). Evaluation on integrated innovation capability of regions based on principal component analysis. Canadian Social Science, 12 -19.

Rachman, F. F. (2017, Februari 21). detikfinance. Retrieved from https://finance.detik.com/: https://finance.detik.com/beritaekonomi-bisnis/d-3427718/inidaftar-daerah-dengan-apbd-yangbanyak-habis-untuk-gaji-pns

Sharma, A. (2012). Inter-state disparities in socio-economic development in north east region of india. Journal of Agricultural Science, 236-243.

Todaro, M. P., \& Smith, S. (2006). Economic Development Vol. 9th. . London: Pearson Education Limited.

Waluyo, I. (2010). Akankah Pemerintah Daerah Bangkrut Karena Kenaikan Gaji Pegawai Daerah? Efisiensi, 50 58.

Wandira, A. (2013). Pengaruh PAD, DAU, DAK, dan DBH terhadap Pengalokasian Belanja Modal. Accounting Analysis Journal, 44 - 51.

Xiajing, D., \& Junjie, Z. (2011). The TOPSIS Analysis on Regional Disparity of Economic Development in Zhejiang Province. Canadian Social Science, 135-139. 